\title{
Women in Forestry in the Developing World
}

\author{
by \\ by Regan Dickinson ${ }^{1}$ and J.V. Thirgood ${ }^{1}$
}

\section{Introduction}

Since fuelwood accounts for roughly nine-tenths of all wood used in the developing world, women are the principal users of forest products. As such, they would have good reason to expect forest management to be closely tailored to their needs. In practice, the reverse is usually the case. When foresters seek local advice they turn, as men, to the men in the household or village - men whose perceptions of what is needed or suitable will often be quite different from those of women. Even when women act as heads of households, as is the case surprisingly often, they tend to be ignored in forest management. By failing to involve women, foresters not only fail to meet women's needs but also lose the opportunity to benefit from their unique knowledge of what trees are appropriate.

This report will cover women's involvement and integration in reforestation and other development projects. It will also cover the need for change in perception of women's needs and role in decision-making. Since women play an essential part in reforestation projects they should have a say in what is done.

\section{Women's Use of Fuel in Developing Countries}

Anyone who knows anything about the third world cannot separate women from the forest. More than men, they are in close and daily contact with trees and plants, and they are familiar with their properties and uses. In a survey conducted in Sierra Leone, women were able to name 31 forest products, while men could name no more than eight! The reason is simple: throughout the world, women are usually responsible for feeding the family. Can we even begin to imagine what this simple statement implies in the context of a developing country?

Cooking food is obviously important to feeding the family. The staples of the third world diet are cereal, tubers and root vegetables. They cannot be eaten raw, so there is a close relationship between the supply of fuel and the quality of nutrition in the developing countries. The FAO estimates that three billion people will face a shortage of firewood by the end of this century. In some countries, gathering firewood already means endless treks on foot - an annual total of 60 working days, according to World Bank calculations.

Women in the third world countries are the primary users of forestry products such as fuelwood, wildfoods and fodder. Wood et al. (1980) noted that women "are primarily

Student and Professor, International Forestry Programme. The University of British Columbia, Vancouver, B.C. V6T 1W5 responsible for wood collection and utilization and often the initial establishment and tending of the wood stock around the village." Bennett (1981) found that $78 \%$ of the fuel collection in Nepal was done by women, with $85 \%$ done by women and girls combined. In 1980, the Expert Group on Women and Forest Industries of the UN Economic and Social Commission for Asia and the Pacific reported that as much as two-thirds of the time spent collecting fuelwood was contributed by women (ESCAP, 1980).

Fuelwood shortages in many areas of the world are particularly severe for the poor and the landless. In some parts of the world they are only able to cook one meal a day. Within the household, it is the women who are most affected, because this scarcity increases their work disproportionately. Digerness (1977) points out that in 1967 in Bara, the Sudan, fuelwood was available after a 15- to 20-minute walk from the village; 10 years later women had to walk for at least 1 to 2 hours. Eckholm (1975) made a similar observation about Nepal.

One way of alleviating fuelwood shortages is in improved wood stoves since they use less wood for cooking. One stove developed in the severely deforested highlands of Guatemala, is called the Lorena stove and is meant to replace the open fire. Formed from a monolithic block of locally available sand and clay, it was designed to conserve firewood and decrease smoke build-up in the kitchen. Clearly the success of improved wood stoves depends on how much wood is saved in practice, and on whether the stoves are acceptable to the mass of rural users, especially to the women of poor households.

\section{Women's Other Duties and Uses of Forest Products}

In most rural societies women are not just housewives, but are also farmers; often they bear the major or sole responsibility for food production. Region by region, country by country, ethnic group by ethnic group, detailed studies have documented the point that women's labour and decision-making are crucial to agricultural production and development (FAO 1982).

A study of 95 developing countries in 1970 found that women made up between $17.5 \%$ (in Central and South America) and $46.2 \%$ (in Sub-Saharan Africa) of the total agricultural labour force (Dixon 1983). If food production alone were considered, these figures would be far higher.

Women are frequently responsible for small-stock husbandry and the feeding of larger livestock, particularly milk 
cows and calves. Thus, agroforestry projects that involve fodder trees, the servicing of crops by trees, or intercropping of crops and trees must include women, since it is often women who grow the crops or care for the livestock that will be involved.

Women may also make different uses of forest products than men. In Indian afforestation programs, for example, men and women often differed in species preference (Sharma 1981). Men are more likely to be interested in forest products for sale and in products with end uses further from home. Women collect fuelwood as well as food for both humans and animals from forests and individual trees. They know how various species burn and what species have food value. Both men and women make medicine from forest products, but for different purposes. Women also use forest products for purposes such as basket-making and dyeing.

Women are fully aware of what will be lost if certain species disappear, and they are familiar with the advantages and disadvantages of trees being planted as replacements. Thus, in Burkina Faso, women criticized eucalyptus plantations when they met in 1983 with Marilyn Hoskins, the pioneer of integration of women in forestry. They wanted to see multi-purpose species being planted as well as eucalyptus, which yields no fruit or fodder. In another reforestation project an industrial plantation designed to grow firewood for charcoal had focused on replacing the degraded natural forest with fast-growing exotic trees. The project was detrimental to women's work opportunities; it had overlooked their needs for indigenous tree species such as baobab. In the past, local women had gathered numerous resources from these trees for food and medicine, either for their own use, or to cook and sell in the local markets. Now women must go further in search of such resources.

Because of their intimate involvement with forest products and agricultural production, women often know more about environmental problems than men. For example, the implementors of a soil and water conservation project in Mali discovered that local women had already undertaken conservation efforts without which the fruits of the project would have been destroyed (Hoskins 1982). Wiff (1984) describes a reforestation and soil conservation project in which women were deliberately denied access to credit and technical support (FAO, 1977). Nevertheless, in places where women could work even without access to credit, they led conservation efforts.

\section{The Need for Greater Involvement and Integration of Women Into Development Projects}

Women are not passive members of communities in which public influence and action are restricted to men. March and Taggu (1982) have documented the important influence of women's informal associations in both the private and public sphere. Within the domestic sphere, women exercise influence on public events through their information links, which are based on lineage ties, and on their ability to withhold goods (food, beer) necessary for men's public participation.

Women's solidarity groups may be very active in defending their own interests. For example, in the famous Nigerian "Women's War" of 1929, incensed over the rumor that an ongoing census meant that they were about to be taxed, women refused to allow census takers to count them or their property. Women organized confrontations with the colonial administration that at times led to the use of armed force (March and Taggu 1982). In Kenya, during the United Nations Conference on Energy in March 1980, the women of the KENGO association organized a demonstration to emphasize the urgency of reforestation. In India, in 1973, the Chipko women's movement was able to halt devastation of the forest in Uttar Pradesh, simply by clinging to the trees that were to be cut down.

More representation of women in developing projects is needed because households headed by women are increasingly common and women are assuming new roles. Women-headed households are sometimes the result of personal events such as death of a spouse, divorce, desertion or abandonment, or of social trends such as male outmigration. Sometimes this is by choice. Whatever the cause, households headed by women occur in substantial numbers in every region of the world. Indeed Buvinic and Youssef (1978) estimated that between 25 and 33\% of all households are de facto headed by women.

There is a need for prior consultation with women clients of agroforestry development projects about issues of immediate concern to them and about potential action to solve problems or otherwise improve their lot. This may often mean reordering priorities in project identification, technology design, and species selection to better meet the needs of rural women, especially the poor and heads of households. The employment and training of women in fields already recognized as important (but not exclusively defined as men's work) might then be extended to the training of women for more flexible roles in agroforestry extension programs for rural families, including subsistence farmers and smallholders.

The failure to include women in agroforestry projects has several detrimental effects. It excludes from project benefits the increasing proportion of rural households headed by women. It may prevent project designers from benefiting from women's special knowledge. It may exclude (or even harm) activities and commodities such as fuelwood, basket-making and minor forest products, which are part of women's economic sphere. The participation of women is essential for the success of agroforestry projects, but such participation may, in the long run, also require changes both in approach and in the nature of personnel in forestry and extension departments.

Reforestation and other projects need to integrate women at an equal level with men. With the impact of development programs and the introduction of new technologies, further inequities and negative factors have affected women, intensifying their work burdens and preventing them from contributing to development. Some project efforts have supposedly been orientated especially toward women, but they tend to be superficial and marginal, often confined to such tasks as sewing, menu-preparing and child-care. Such a trend may, in fact, hamper women's integration into broader development processes. Even the newer appropriate technology projects, which often contain sincere efforts to include women's participatory action, have not avoided some of the traditional biases and problems, and still tend to perpetuate male-orientated dependency relationships, patriarchal organizations and technocratic approaches.

Women in developing countries need more training and land ownership. In some countries, if a woman tries to work on a farmstead, she lacks the credit needed to develop it because she does not have a title or land-ownership deed to 
back her. Although this problem also arises with men; it is less frequent. Effective training systems must be made available to women, keeping in mind the other activities they must perform daily, and offering the right training for the change in activities they will have to undertake, involving simple programs that will progressively improve their education. The programs must be based on appropriate technology with easily applicable practices and methods, e.g., the adoption of implements normally employed and easy to use (hoes, spades, rakes, machetes), which the women can also buy with their own earnings or through specific programs.

Ideas and attitudes need to change, both abroad and here at home. Integrating women in development must not remain a lofty principle given no more than lip service through speeches and applause at international conferences. Nor must it be just a parallel activity, the poor relation of development cooperation. The integration of women must be a real and essential element of every project, from the original concept to final evaluation of the results.

Women's groups should be encouraged to address power relations and political issues and they should not be coopted into existing structures that mute their potential contribution. Women's efforts will not have full impact if they remain mere depoliticized "pawns" or peripheral actors in other people's development schemes. Rather, they need autonomy, visibility and decision-making centrality, as well as political and economic power in an area they know intimately. With appropriate orientations, they can contribute greatly toward relieving their own burdens, averting wood-scarcity problems, building socially beneficial resource projects and promoting the broader goals of development.
References

Agarwal, Bina. 1983. Why are stoves resisted? Unasylva 35(140): 22-27.

Bennett, L. 1981. The Parbatiya women of Bakandal. In The Status of Women in Nepal. Vol. 2(7). Kathmandux Cent. for Econ. Dev. and Admin.

Buvinic, M. and N.H. Youssef. 1978. Women-headed households: The ignored factor in development planning. Intern. Cent. for Res. on Women. Washington, D.C.

Digerness, T.H. 1977. Wood for fuel - the energy situation in Bara the Sudan. Dep. Geogr., Univ. Bergen, Norway. (Mimeo.)

Dixon, R. 1983. Land, labour and sex composition of the agricultural labour force: An international comparison. Dev. Change 14: 347-372.

Eckholm, E.P. 1975. The other energy crisis. World Watch Inst. Pap. No. 1.

ESCAP. 1980. Report of the expert group meeting on women and forest industries. Bangkok.

FAO Committee on Agriculture. 1982. Follow-up to WCARRD: The role of women in agricultural production. FAO, Rome.

Fortmann, L. and D. Rocheleau, 1984. Why agroforestry needs women: Four myths and a case study. Unasylva 36(146): 2-10.

Hoskins, M. 1982. Social forestry in West Africa: Myths and realities. Pap. given at ann. meet. Amer. Assoc. Adv. Sci., Washington, D.C.

March, R. and R. Taggu. 1982. Women's informal associations and the organizational capacity for development. Cornell Univ. Rural Dev. Comm., Ithaca, N.Y.

Sharma, R. 1981. Greening the countryside. New Delhi Inf. Serv. on Sci. and Soc. Related Issues, Cent. for Sci. and Environ: 1-4.

Thrupp, Lori-Ann. 1984. In Kenya and beyond. Unasylva 36(146): 37-42.

Wiff, Mercedes. 1984. Women make a start in agroforestry: Unasylva 36(146): 21-26.

1977. The role of silviculture in rural development in Latin America. Annex to Rep. on FAO/SIDA Seminar. FAO, Rome.

Williams, Celine. 1986. Forestry is women's business too. CIDA Development: Forests. Autumn Issue: 25-27.

Wood, D.H. 1980. The socio-economic context of firewood use in small rural communities (Devres Inc.). A.I.D. Evaluation Study No. 1. Agency for International Development. Washington, D.C. 293. pp.

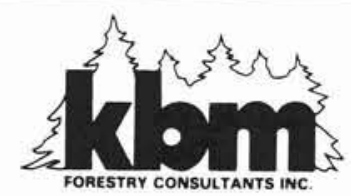

REFORESTATION EQUIPMENT

- Sales Service Parts Repair

REGENERATION \& SITE PREPARATION

- Contract Assessment Consulting

807-344-0811 telex 073-4603 